\title{
SPATIOTEMPORAL CHANGE ANALYSIS OF THE PROTECTED AREAS: A CASE STUDY - İĞNEADA FLOODPLAIN FORESTS
}

\author{
M. Toker ${ }^{1 *}$, E. Çolak ${ }^{2}$, F. Sunar ${ }^{2}$ \\ ${ }^{1}$ Ministry of Agriculture and Forestry, 06560 Beştepe, Ankara, Turkey merve.toker@tarimorman.gov.tr \\ ${ }^{2}$ ITU, Civil Engineering Faculty, Geomatics Engineering Department, 80626 Maslak Istanbul, Turkey (colakem, fsunar)@itu.edu.tr
}

KEY WORDS: Protected Areas, Landsat TM time series, Google Earth Engine, Landtrendr analysis, Spatiotemporal Changes.

\begin{abstract}
:
Protected areas are important with land or water body ecosystems that have biodiversity, flora and fauna species. In Turkey, National Parks are one of the protected areas managed according to the National Parks Law No. 2873. Among them, the İgneada Floodplain Forests National Park, located in İğneada town in the province of Kırklareli, Turkey has been declared as a national park in 2007, and has an importance being a rare ecosystem, which consists of wetland, swamp, lakes and coastal sand dunes. Planning of Protected Areas can be done in a variety of ways, taking into account the balance of protection/use and should follow policies and guidelines. Today, for the sustainability and effective management of forest ecosystems, remote sensing technology provides an effective tool for assessing and monitoring ecosystem health at different temporal and spatial scales. In this study, potential temporal changes in the National Park were analyzed with Landsat satellite time series images using two different methods. First method, the Landtrendr algorithm (Landsat-based Detection of Trends in Disturbance and Recovery) developed for multitemporal satellite data, uses pixel values as input data and analysis them by using regression models to capture, label and map the changes. In this context, Landsat satellite time series images were taken quinquennial between 1987 and 2007 and biennially until 2017 for Landtrendr analysis (i.e. before and after its declaration as a National Park, respectively). As a second approach, the Google Earth Engine (GEE) cloud-based platform, which facilitates access to high-performance computing resources to process large long-term data sets, was used to analyze the impact of land cover changes. The results showed that the area was subjected to various pressures (i.e. due to illegal felling, pollution, etc.) until it was declared as a National park. Although there was general improvement and recovery after the region declared as a Park, it was seen that the sensitive dynamics of the region require continuous monitoring and protection using geo-information technologies.
\end{abstract}

\section{INTRODUCTION}

The increase in human population leads to an increase in local and global environmental stresses by consuming biodiversity and human-dependent resources. Today, natural and cultural efforts to develop various conservation methods and tools for protecting natural resources are increasing. The most advanced of these efforts is internationally recognized protected area applications. National Parks, one of the important protected (or protected) areas, where "non-intervention" prevails and the principle is to allow the free evolution of natural processes. They have unique meaning because of its own habitat, endemic or historical sources and provide invaluable economic, social, cultural and health benefits. Today, it is critical to effectively manage these areas (Ministry of Forestry and Water Affairs, 2013).

Protected areas are critical for preserving biodiversity, reducing the risk of endangered species and habitats, and maintaining the continuity of ecological relations and processes around the world. They are important for each country and range from areas where recreational activities are entirely prohibited or strictly controlled, including protection activities, recreation activities and certain arrangements with human settlements. The compaction of the soil, the destruction of vegetation, and the disturbance of biodiversity in protected areas as a result of tourism-oriented and recreation uses causes critical environmental issues, as well as many negative effects such as pollution, noise, flora and fauna loss, and forest fire (Akten et al., 2012; Ministry of Forestry and Water Affairs, 2013).

*Corresponding Author
Turkey has many important conservation areas and about $1 \%$ of the total area consists of the National Park. One of these is the İgneada Floodplain Forests National Park, which is worldrenowned for its ecological diversity and rare flood forests, and was preserved as a National Park in 2007. The forest area houses a rich variety of plants, trees, animals and birds as well as numerous water creatures living in its many lakes. The İğneada Floodplain forests, completely covered with water during winter and spring, has a floristic composition of mixed forest trees. These forests, not only for Turkey, but also is a natural asset for Europe, the protection of the habitat of these forests has crucial importance (Toker, 2018).

Today, space technologies such as remote sensing provide very promising and effective tools that help to continuously monitor habitat types and their conservation status assessments, with synoptic views of large areas such as forests at different times. Vital information extracted by remote sensing include land cover types and changes, landscape patterns, vegetation conditions, plant phenology, etc. This detection and characterization of changes in key resource characteristics allows resource managers to monitor landscape dynamics in large areas (Luft et.al, 2014).

For the land cover change analysis and monitoring the landscape dynamics, spectral vegetation indexes such as Normalized Difference Vegetation Index (NDVI) data, which is a measure of photosynthetic behaviour, plant greenness, and condition, is one of the most powerful indicator for assessing natural and anthropogenic impacts on vegetation at landscape-scale (Çolak and Sunar, 2020a, 2020b; Akkartal, et.al, 2004). Hence, this continuous valuable information obtained by multi-temporal satellite images allows to determine the reference conditions for understanding and predicting ecosystems response against 
environmental perturbations or management actions, and also their directional changes (trends). For trend analysis, the Landtrendr Algorithm, a new algorithm based on the Landsat time series, is now being used as an effective tool that takes into account pixel-based temporal trajectories.

This study also contributes to the application of cloud computing Google Earth Engine (GEE) and its potential for monitoring the landscape dynamics and changes. Recently, GEE is being used for environmental data analysis that can determine important parameters from different satellite time series images. GEE offers freely available multi-temporal (time series) satellite data. These time series can be computed without the need for a priori scene selection, reducing the time it takes to generate satellite data sets within a given date range (Çolak and Sunar, 2020c).

Hence, this study aims to analyze potential changes in İgneada Floodplain Forests National Park using Landtrendr algorithm for the period of 1987 - 2017 and GEE for the period of $1984-2019$ with Landsat satellite time-series images.

\section{STUDY AREA \& DATA USED}

The İgneada Floodplain Forests National Park, declared as a national park in 2007 and now administered by the DirectorateGeneral of Nature Protection and National Parks, is located within Kurklareli Province (27-28 degree longitude and 41-42 degree latitude) in Marmara Region of Turkey.

As can be seen in Figure 1, the National Park consists of two parts and İgneada settlement is situated among them. The National Park is a rare ecosystem of international importance and priority on a European scale, and consists of a wide range of flora and fauna, including floodplain, deciduous mixed forests, wetlands, coastal sand dunes, and five lakes (namely Saka, Mert, Deniz, Hamam, Erikli, and Pedina). It is also located on major bird migration routes (Ministry of Forestry and Water Affairs, 2014).

For Landtrendr analysis, Landsat satellite time series images were taken quinquennial between 1987-2007 and biennially until 2017 before and after the declaration, respectively (Table 1). To reduce seasonal effects, images were selected to be as close as possible to the same seasons (i.e. preferably in summer, when forests and other plants in this region begin to vegetate earlier than other plants, since alluvial soils have more intensive microorganism activities). All summer cloudless Landsat time series season available on the GEE platform (198 images) were used to monitor vegetation changes in the area.

\section{METHODOLOGY}

Two methods were applied in pixel-based temporal trajectory analyses. These are Landtrendr (Landsat-based Detection of Trends in Disturbance and Recovery) algorithm which is developed for multi-temporal satellite data, and Google Earth Engine (GEE) platform, which hosts huge dataset to analyze and visualize geospatial dataset for different aims.

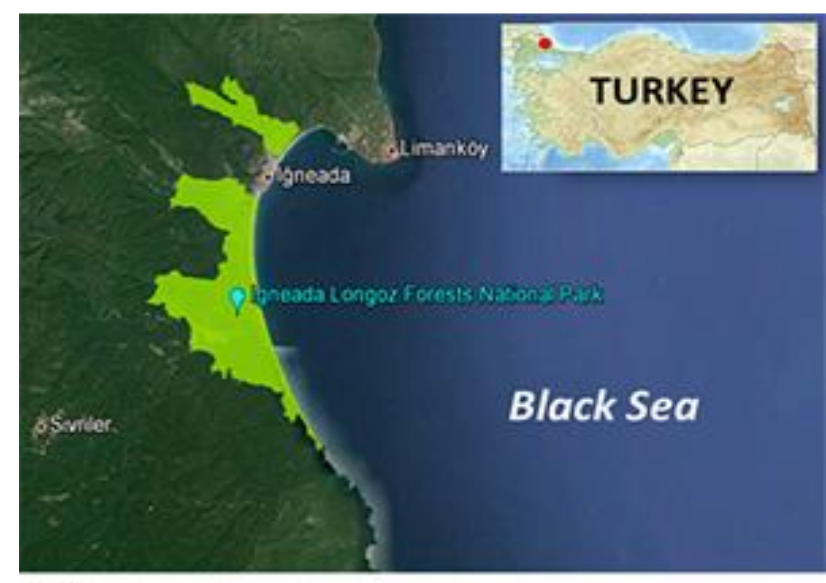

(a)

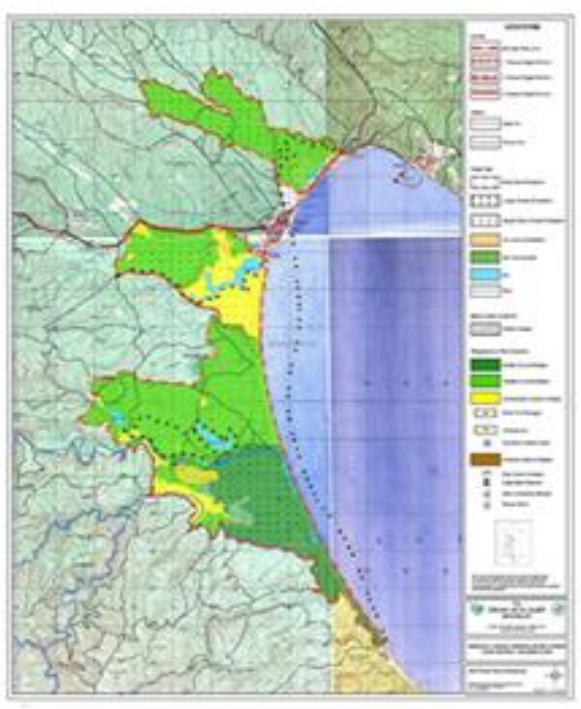

(b)

Figure 1. The location (a) and plan (b) of İğneada Floodplain Forests National Park (LTDRP, 2016).

\begin{tabular}{|c|c|c|c|c|c|}
\hline Satellite & Date & \multicolumn{2}{|c|}{$\begin{array}{l}\text { Spectral Res. } \\
(\mu \mathrm{m})\end{array}$} & $\begin{array}{c}\text { Spatial } \\
\text { Res. } \\
(\mathbf{m})\end{array}$ & $\begin{array}{c}\text { Temporal } \\
\text { Res. } \\
\text { (day) } \\
\end{array}$ \\
\hline \multirow{7}{*}{$\begin{array}{l}\text { Landsat } \\
\text { TM }\end{array}$} & 15.8 .87 & B1 & $0.45-0.52$ & \multirow{7}{*}{30} & \multirow{7}{*}{16} \\
\hline & 28.8 .92 & B2 & $0.52-0.60$ & & \\
\hline & 25.7.97 & B3 & $0.63-0.69$ & & \\
\hline & \multirow{4}{*}{$\begin{array}{c}14.6 .02 \\
5.7 .07 \\
24.6 .09 \\
17.8 .11\end{array}$} & B4 & $0.76-0.90$ & & \\
\hline & & B5 & $1.55-1.75$ & & \\
\hline & & B6 & $10.40-12.50$ & & \\
\hline & & B7 & $2.08-2.35$ & & \\
\hline \multirow{11}{*}{$\begin{array}{l}\text { Landsat } \\
\text { OLI }\end{array}$} & \multirow{11}{*}{$\begin{array}{c}6.8 .13 \\
12.8 .15 \\
1.8 .17\end{array}$} & B1 & $0.435-0.451$ & \multirow{11}{*}{30} & \multirow{11}{*}{16} \\
\hline & & B2 & $0.452-0.512$ & & \\
\hline & & B3 & $0.533-0.590$ & & \\
\hline & & B4 & $0.636-0.673$ & & \\
\hline & & B5 & 0.851-0.879 & & \\
\hline & & B6 & 1.566-1.651 & & \\
\hline & & B7 & $2.107-2.294$ & & \\
\hline & & B8 & $0.503-0.676$ & & \\
\hline & & B9 & $1.363-1.384$ & & \\
\hline & & B10 & 10.60-11.19 & & \\
\hline & & B11 & $11.50-12.51$ & & \\
\hline
\end{tabular}

Table 1 Landsat satellite images used in Landtrendr analysis. 


\subsection{Landtrendr algorithm}

Landtrendr algorithm is a new algorithm based on Landsat time series with extracting temporal trajectories of a land surface (Figure 2). The image pixels which may have a change, are determined by applying the algorithm to the time series images and then the abrupt changes and/or temporal changes can be detected (Kennedy, et al., 2010). For detecting temporal change on forest cover and water body, Normalized Difference Vegetation Index (NDVI) was used as input dataset in Landtrendr algorithm. NDVI is an index for extracting the green plant information using Visible-Red and Near-infrared bands. The index result is always between -1 to 1 values (i.e. highly vegetated area has NDVI value close to 1) (Sunar, et al., 2011).

(a)

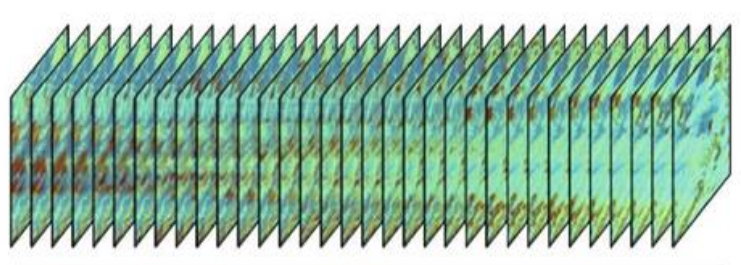

(b)

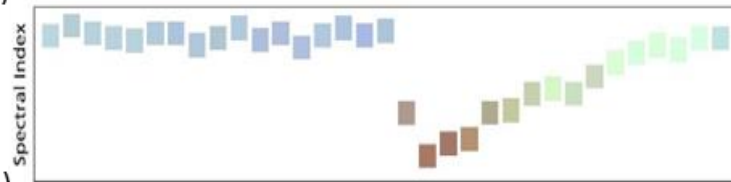

(c)

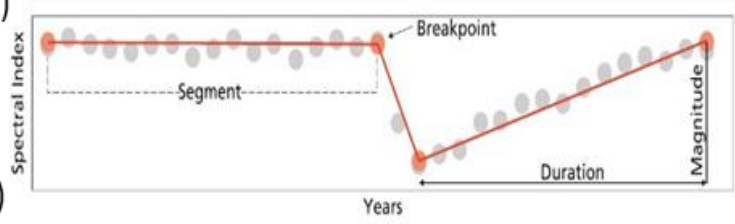

Figure 2. Change detection concept of Landtrendr algorithm. (a) Each pixel in the best available yearly composite between 1987 - 2017, (b) contributes to a trajectory of the NDVI (c) LandTrendr then detects magnitude, duration and timing of disturbance in the trajectory (de Jong et al., 2021).

\subsection{Google Earth Engine (GEE)}

Given the high amount of image download and processing required, cloud platforms such as Google Earth Engine provides fast rendering services critical to rapid landscape changes enabling to host huge dataset to analyze and visualize time series data.

\section{APPLICATION \& RESULTS}

\subsection{Selection of Test Regions}

For the selection of test regions, the areas that may change were taken into account. Forest areas that were particularly important for the ecology of the region were considered. Within this framework, two different forest regions were selected for change detection analysis: floodplain forest near Mert Lake and mixed forests in the middle part (Figure 3).

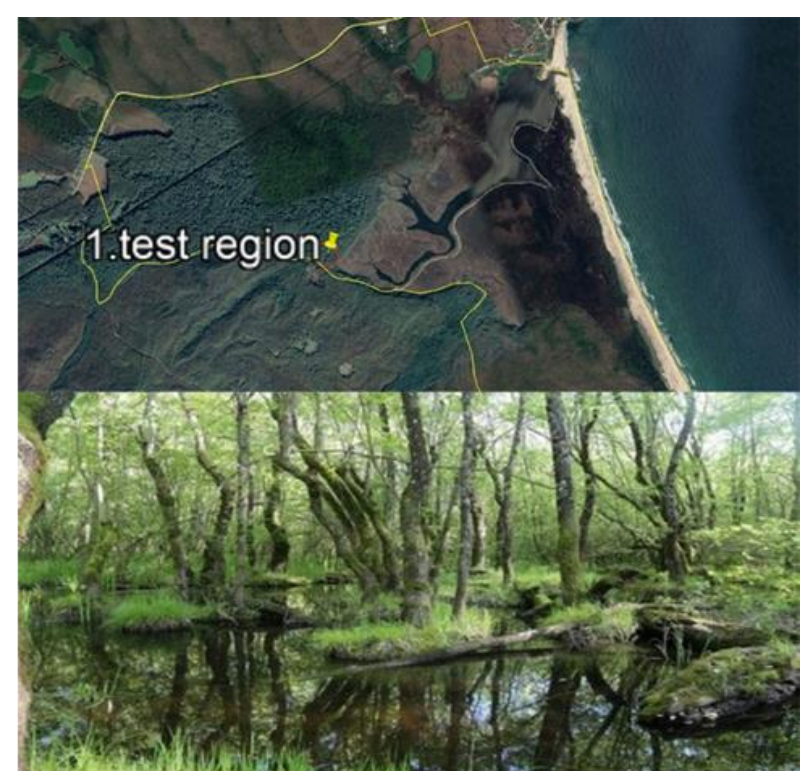

(a)

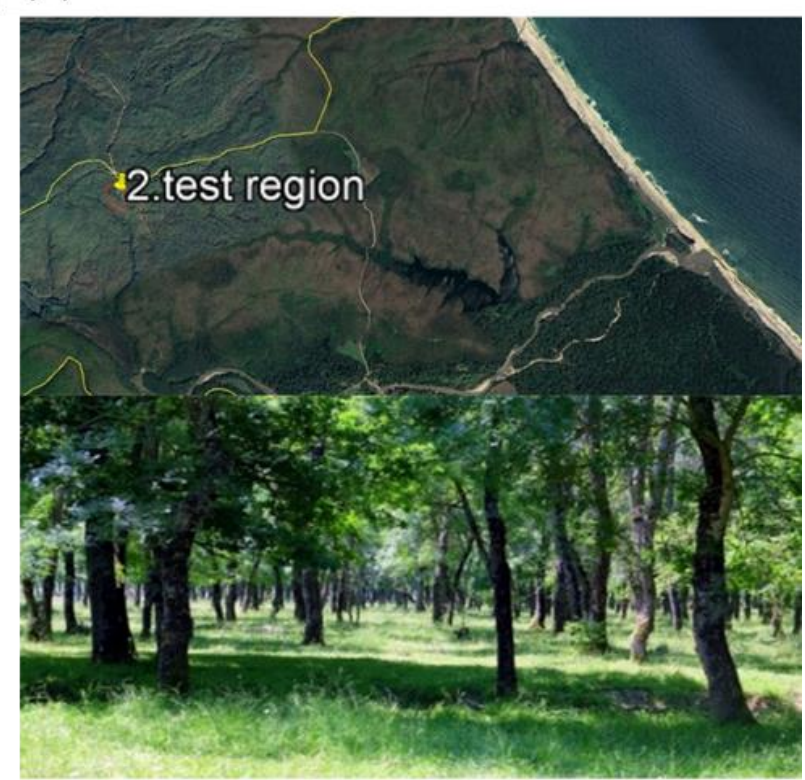

(b)

Figure 3. Location of 2 test regions and field photos.

(a) Floodplain forest. (b) Mixed forest.

\subsection{Landtrendr Algorithm}

Before applying the first approach, the Landtrendr algorithm, the images were normalized using NDVI index. Then the time series were produced with the pixel values of all years for the selected regions and the spikes were tested before the regression analysis. The linear trend model was applied to the time series, which are cleaned out of the outliers. According to the results, the series were divided from the point where the deviation is maximum and regression models were applied for both divided time series. This process was continued until the maximum number of segmentations was reached. After the potential models created, the f-test size and the corresponding probability values ( $p$ value) were calculated for each model. By looking at the probability (p) values, the suitable model was chosen (Kayikci and Sopac1, 2015). The flowchart of the Landtrendr algorithm used is given in the Figure 4. 


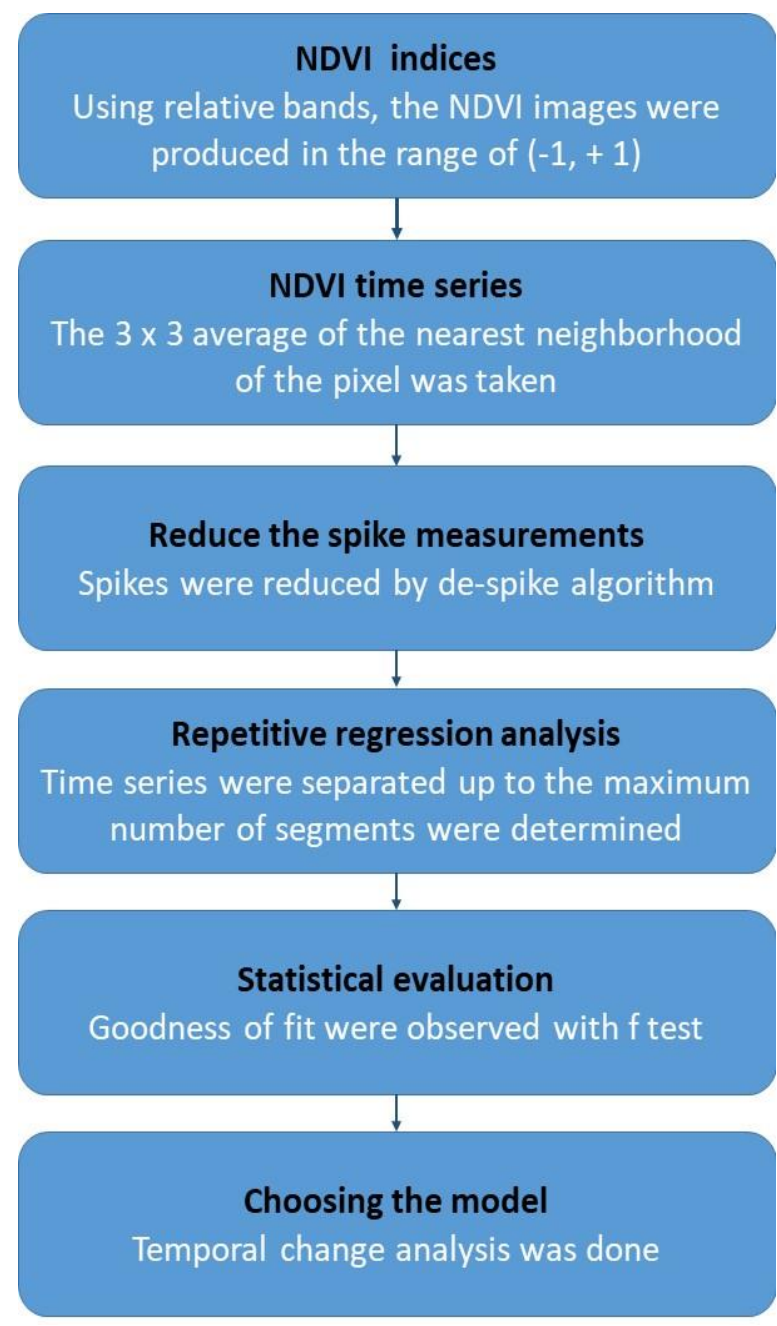

Figure 4. The flowchart of the Landtrendr algorithm used (Toker, 2018).

\subsection{GEE Analysis}

For the second approach which is used to assess vegetation changes, Landsat NDVI data between 1984-2019 were taken from the GEE platform and visualized as a time series graph.

\subsection{First test region (Floodplain forest area)}

The raw time series of NDVI and three different regression models with $\mathrm{p}$ values obtained after $\mathrm{f}$ statistics test, were shown respectively in Figure 5(a) and Figure 5(b). In the first and second regression models, it was seen a continuous increase at the forest cover. It was determined that the result of the third and the best fitted model, which successfully identified the spikes and decrease in the forest cover for $1997-2007$ period, was caused by the İgneada settlements sewage dumped into Mert Lake (World Wildlife Foundation, Ministry of Environment and Forestry, 2007).

Figure 5(c) shows the GEE NDVI time series of this test region for the summer season between 1984 and 2019. First, the GEE NDVI time series was found to be compatible with the Landtrendr algorithm. In other words, the average NDVI value (i.e. 0.70) in the 1987 - 2007 period is lower than in the 2008 -
2019 period (i.e. 0.75). Second, the average NDVI values in this region tend to fall slightly from June to August ( 0.73 in June; 0.72 in July; and 0.68 in August), proving that forests and other plants begin to vegetate earlier than other plants.

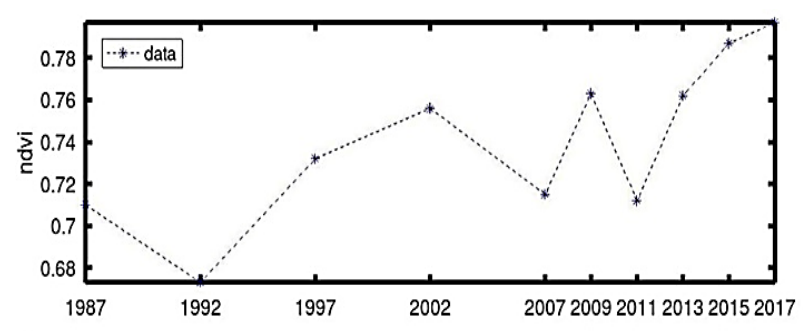

a
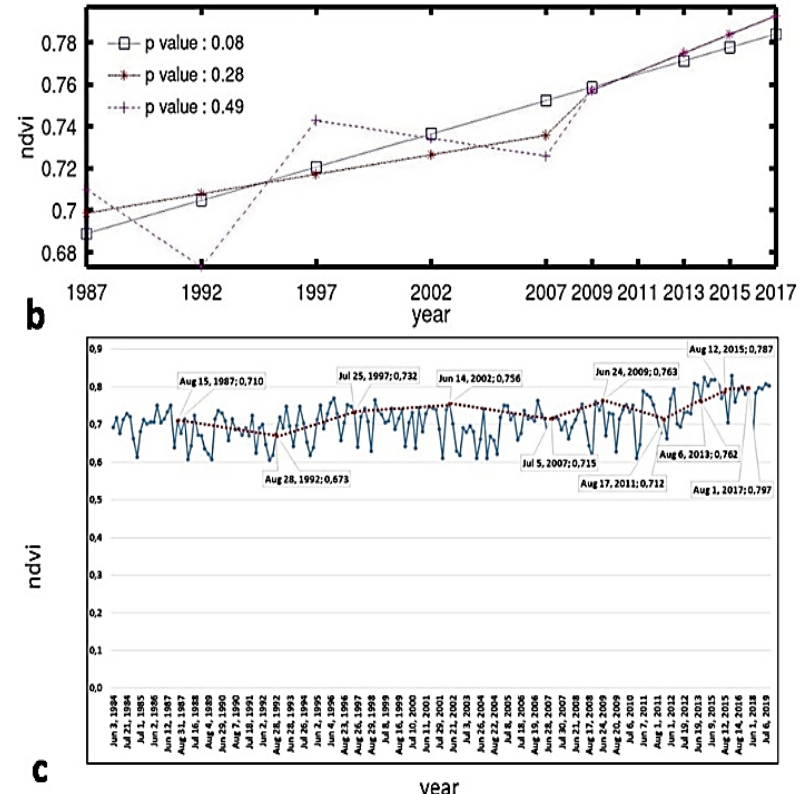

Figure 5. Landtrendr Algorithm results for the first test region, (a) Raw time series, (b) Three different regression models with $\mathrm{p}$ values obtained after $\mathrm{f}$ statistics test, (c) GEE NDVI time series.

\subsection{Second test region (Mixed forest area)}

Figure 6(a) shows the raw time series of NDVI images and Figure 6(b) includes three different models and their $\mathrm{p}$ values according to $f$ test. Although the first model was not fitted well enough, the second model could detect some changes. The third and best fitted model successfully determined the general recovery of the test area after declaration as a National Park. Before its declaration, it was stated that the decrease in vegetation was due to illegal felling (Turkish Grand National Assembly, 2004). 


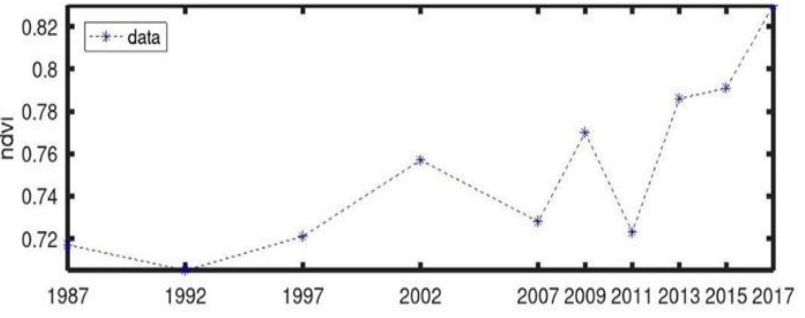

a
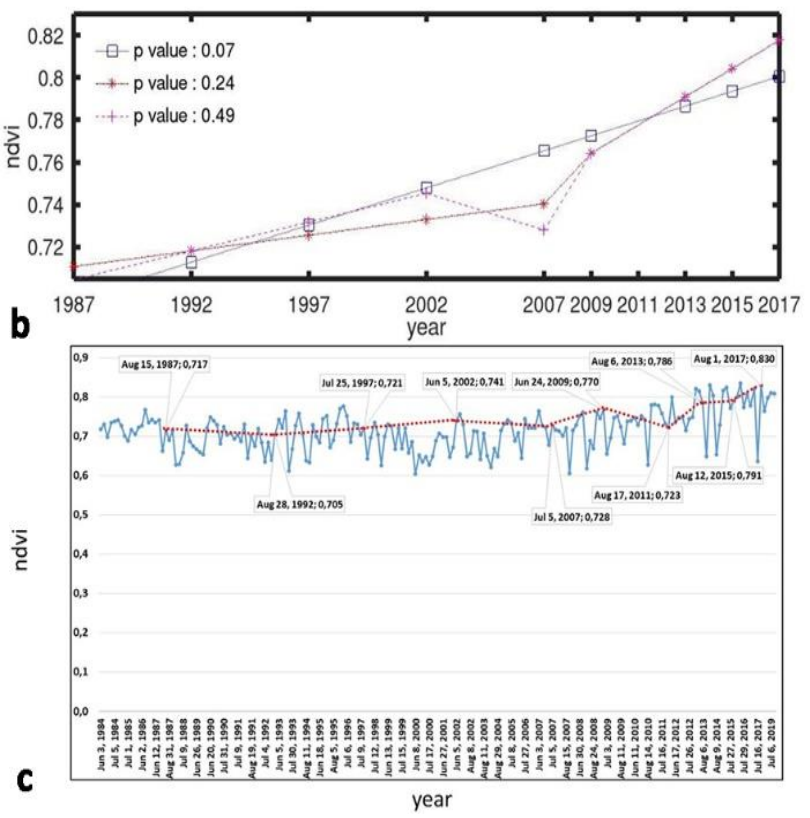

Figure 6. Landtrendr Algorithm results for the second test region, (a) Raw time series, (b) Three different regression models with $\mathrm{p}$ values obtained after $\mathrm{f}$ statistics test,

(c) GEE NDVI time series.

\section{CONCLUSION}

Protected areas account for $12 \%$ of the world. This ratio is approximately $1 \%$ in Turkey. While the number of protected areas is increasing day by day, these areas need to be managed and monitored effectively. In addition to effective management requirements, a legal basis should be established with appropriate legal policies for these specific regions. In this study, vegetation dynamics of the İgneada Floodplain Forest National Park, declared as a national park due to being a rare ecosystem of international importance and priority on a European scale, was examined using Landsat time-series satellite images.

To improve the results of the Landtrendr algorithm, the number of regression models can be increased by using more satellite images, so that the most appropriate model can be selected from more model options (i.e. using different statistical tests). On the other hand, seasonal impacts can also be examined using multitemporal image dataset available in other cloud computing resources, such as offered by NASA Earth Exchange (NEX) or Amazon Web Service (AWS).

This study aims to provide a new perspective on the sustainability of protected forest areas by demonstrating the effectiveness of remote sensing technology used as an effective tool for monitoring natural resources. Based on the findings of this study, it can be concluded that geo-information technologies, including remote sensing, are useful in making urgent decisions by providing prompt vegetation trend information for environmentally important ecological areas such as the İğneada Floodplain Forest National Park. As shown, the area was subjected to various pressures during the period (i.e. due to illegal felling, pollution, etc.) until it was declared as a park in 2007. Although there is a general improvement and a recovery in the ecosystem after its declaration as a National Park, it is seen that due to its sensitive dynamics, the region should be regularly monitored with geo-information technologies.

\section{REFERENCES}

Akten, S., Gül, A., Akten, M., 2012. Korunan Doğal Alanlarda Kullanılabilecek Ziyaretçi Yönetim Modelleri ve Karşılaştırılması [Visitor Management Models That Can Be Used in Protected Natural Areas and Their Comparison]. SDÜ Orman Fakültesi Dergisi 13, 57, 65.

Akkartal, A., Türüdü, O., Sunar Erbek, F., 2004. Analysis of changes in vegetation biomass using multi-temporal and multisensor satellite data." In XXXV ISPRS Congress, pp. 12-23. 2004.

Çolak, E., Sunar, F. 2020a. Evaluation of forest fire risk in the Mediterranean Turkish forests: A case study of Menderes region, Izmir. International journal of disaster risk reduction 45, 101479.

Çolak, E., Sunar, F. 2020b. Spatial pattern analysis of post-fire damages in the Menderes District of Turkey. Frontiers of Earth Science 14(2), 446-461.

Çolak, E., Sunar, F., 2020c. The importance of ground-truth and crowdsourcing data for the statistical and spatial analyses of the NASA FIRMS active fires in the Mediterranean Turkish forests. Remote Sensing Applications: Society and Environment 19, 100327.

de Jong, S. M., Shen, Y., de Vries, J., Bijnaar, G., van Maanen, B., Augustinus, P., Verweij, P., 2021. Mapping mangrove dynamics and colonization patterns at the Suriname coast using historic satellite data and the LandTrendr algorithm. International Journal of Applied Earth Observation and Geoinformation 97, 102293.

Luft, L., Neumann, C., Freude, M., Blaum, N., Jeltsch, F., 2014. Hyperspectral modeling of ecological indicators - A new approach for monitoring former military training areas. Ecological Indicators 46, 264-285.

Kayıçı, E. T., Sopacı, E., 2015. Testing the normality of the residuals of surface temperature data at VLBI/GPS co-located sites by goodness of fit tests. Arabian Journal of Geosciences 8(11), 10119-11134.

Kennedy, R. E., Yang, Z., Cohen, W.B., 2010. Detecting trends in forest disturbance and recovery using yearly Landsat time series: 1. LandTrendr - Temporal segmentation algorithms. Remote Sensing of Environment 114(12), 2897-2910.

Ministry of Forestry and Water Affairs, 2013. Forestry and water council report, Ankara.

Ministry of Forestry and Water Affairs, 2014. İgneada floodplain forests national park long term development plan, Ankara.

Ministry of Forestry and Water Affairs, 2016. İğneada floodplain forests national park long term development revision plan, Ankara. 
Ministry of Environment and Forestry, 2007. Biodiversity and natural resources management project, İğneada management plan, Ankara.

Sunar, F., Özkan, Ç., Osmanoğlu, B., 2011. Remote sensing (in Turkish), Anadolu University press, Eskişehir

Toker, M., 2018. Temporal change detection analysis using landsat and sentinel satellite images: A case study-Igneada floodplain forest national park (M.Sc thesis), İstanbul Technical University, İstanbul.

Turkish Grand National Assembly, 2004. Journal of official report, Ankara, 258-260.

World Wildlife Foundation, Ministry of Environment and Forestry, 2007. İğneada conservation area planning and management report, Ankara. 